II

Worlds 


\title{
3
}

\section{Music and Romantic Literature}

\author{
Miranda Stanyon
}

\section{Introduction}

\author{
Heard melodies are sweet, but those unheard \\ Are sweeter; therefore, ye soft pipes, play on
}

- Keats, 'Ode on a Grecian Urn' (1819)

Music is ubiquitous in Romantic literature. To wander through its poetry and prose is to encounter a landscape crowded with obscure village minstrels, prophetic bards, carefree improvisors, cruelly disfigured and rejected castrati, and enthusiastic kapellmeisters ready to cruise the job market. ${ }^{1}$ Genius composers draw us into infinite nocturnal kingdoms (Beethoven), die listening to their own sublime creations (Haydn), and return to life to haunt pubs and opera houses (Gluck). ${ }^{2}$ Here, Sappho's song echoes as she leaps from a cliff; there, a 'Hindoo' girl sings a prediction of her love match; Albanian soldiers 'half-scream' war-ballads in the mountains; medievalising lutes sound mysteriously through the darkness to heroines imprisoned in castles; caged birds sing

\footnotetext{
${ }^{1}$ John Clare, The Village Minstrel (1821); James Beattie, The Minstrel(1774); James Macpherson, Fragments of Ancient Poetry (1760); Letitia Elizabeth Landon, 'The Improvisatrice' (1824); Hans Christian Andersen, The Improvisatore (1835); Joseph von Eichendorff, Aus dem Leben eines Taugenichts (1826); Leigh Hunt, 'Velluti to his Revilers' (1825); E. T. A. Hoffmann, Fantasiestücke in Callot's Manier(1814-19). ${ }^{2}$ Hoffmann, 'Beethovens Instrumental-Musik' (1810) and 'Ritter Gluck' (1809/14); Heinrich von Kleist, 'Über Haydns Tod' (1811).
} 
in praise of Waldeinsamkeit, while nightingales vie for airtime with the silent pipers on an antique urn. ${ }^{3}$

And this din largely covers just one dimension of the relationship between literature and music: the representation of music in literary texts. Just as significant for Romanticism was the new twilight zone between literature and music theory or criticism, epitomised by E. T. A. Hoffmann's publications of the same material in music journals and collections of 'literary' Fantasiestücke. Finally, there is the enormous territory of Romantic literature in music, most strikingly poetry settings in lieder, and adaptations of prose for operas, melodramas, and instrumental works (Mérimée’s novella for Bizet's Carmen; De Quincey's autobiography via Musset for Berlioz's Symphonie fantastique; Dumas fils's play for Verdi's La traviata; Hugo's novel for Claude-Michel Schönberg's Les Misérables).

The task of this chapter is not to survey this vast field, but to ask what work music does for literature in Romanticism. The question is difficult enough, not least given the problems of periodisation endemic to studies of Romanticism. Romanticism is not contemporaneous across European traditions, and nor is literary Romanticism easily synchronised with musical Romanticism. Thus 'Romantic' debates over sublimity, virtuosity and naturalness, spontaneous creativity, and fidelity to the musical work are fought over 'baroque' and 'classical' compositions by Handel, Arne, Mozart, or Gluck. ${ }^{4}$

\footnotetext{
3 Landon, 'Sappho' (1822) and 'The Hindoo Girl's Song' (1835); Lord Byron, Childe Harold (1812), 2.72; Ann Radcliffe, Mysteries of Udolpho (1794); Ludwig Tieck, Der blonde Eckbert (1797); John Keats, 'Ode to a Nightingale' and 'Ode on a Grecian Urn' (1819).

4 See Sarah Hibberd and Miranda Stanyon (eds.), Music and the Sonorous Sublime in European Culture, 1680-1880 (Cambridge: Cambridge University Press, 2020); Gillen D’Arcy Wood, 'The Castrato's Tale: Artaxerxes and the Feminization of Virtuosity', The Wordsworth Circle, 39/3 (2008), 74-9; Günter Schnitzler, "“Ritter Gluck”: Produktive
} 
Related to periodisation are broader definitional problems, not infrequently scorned by Romantic writers themselves ('one feels the romantic, one does not define it', wrote one). ${ }^{5}$ Should we talk of Romantic movements (centred on social groupings and affiliations, and often on canonical artists), Romantic eras and generations (at the risk of implying that a spirit of the age permeates all cultural productions), or of Romantic aesthetics, more or less temporally limited (since, for instance, Friedrich Schlegel famously believed 'all poetry is or should be romantic', a statement difficult to fathom outside the particular moment and milieu of Jena Romanticism (1798-1804))? ${ }^{6}$

As a cluster of values, tendencies, and theories, Romantic aesthetics include engagement with philosophical Idealism, absolutes, and ideals - both 'normative', in the sense that art represented ideals, and 'categorial', in the sense that making and reflecting on art might enact ideals such as freedom, spontaneity, infinite play, indeterminacy, or autonomy. ${ }^{7}$ As autonomous, art was imagined to be non-utilitarian (not difficult in a world where personal patronage was increasingly unreliable), although it could be deeply politically and socially engaged. Romanticism was not, of course, concerned with 'emotion' above 'reason' or 'enlightenment', nor with individual subjectivity against community or society. It was, however, bound up with new

Musikkritik', in Günter Saße (ed.), E. T. A. Hoffmann: Romane und Erzählungen (Stuttgart: Reclam, 2004), 13-30; Rachel Cowgill, 'Mozart Productions and the Emergence of Werktreue at London's Italian Opera House, 1780-1830', in Roberta Montemorra Marvin and Downing Thomas (eds.), Operatic Migrations (Aldershot: Ashgate, 2006), 145-86.

${ }^{5}$ Louis-Sébastien Mercier, Néologie, vol. 2 (Paris: Moussard, 1801), 230.

6 Friedrich Schlegel, Athenäum fragment 116 (1798), in Kritische Schriften, ed. Wolfdietrich Rasch (Munich: Carl Hanser Verlag, 1958), 38.

7 Stefan Matuschek, 'Romanticism as Literary Idealism', in The Impact of Idealism, vol. 3, Aesthetics and Literature, ed. Christoph Jamme and Ian Cooper (Cambridge: Cambridge University Press, 2013), 72. 
understandings of such categories: the dominant paradigm of 'emotions' was crystallising in our period (alongside claims that aesthetic responses are not passionate); and eighteenth-century ideas about the shaping power of the subject's imagination and perception took on new dimensions and urgency, leading some texts to despair of accessing reality through the 'green spectacles' of our own perceptual apparatus (Kleist's letters), others to revere imagination as a 'power' revealing an 'invisible world' superior to empirical experience (Wordsworth's Prelude), and still more to create dialectics between experience as given and self-created. ${ }^{8}$ Although metaphors surrounding imagination were often visual, the (for Romantic authors) emotionally charged and time-saturated medium of music was increasingly both a model for literary production, and a source of metaphors for subjectivity - as when Coleridge calls 'Joy' a 'strong music in the soul', given to us by 'Nature', but becoming 'the life and element' 'Of all sweet sounds' available to perception, 'All melodies the echoes of that voice' (lines 64, 68, 58, 74). These words, from 'Dejection: An Ode' (1802), suggest a final Romantic concern: the idea of a malady - melancholy, madness, solipsism, incurable longing - sometimes seen as a universal human asset, but often identified with specific problems of modernity, be they despotic revolutions, repressive old orders, urban and utilitarian pressures, idleness and loss of old meanings, or alienation - a mal du siècle.

Other chapters in this book help explain music's distinctive and exalted place in this aesthetic, in particular its connection with origins, of languages and peoples, and with ends, the telos of humans' connection with the infinite and undetermined. For our

\footnotetext{
8 Kleist, Sämtliche Werke und Briefe, ed. Helmut Sembdner, rev. ed., vol. 2 (Munich, Deutscher Taschenbuch Verlag, 2001), 634; William Wordsworth, Prelude (1805), book 6, lines 530, 539.
} 
purposes, it suffices to recall the musicological argument that the failures of music within (narrowly) representational artistic paradigms became a strength when representation was seen as limited and determined, making music, in Hoffmann's words, 'the most Romantic of all the arts ... for only the infinite is its object'. ${ }^{9}$ This leaves verbal arts in an uncomfortable position. They not only habitually represent and refer (although texts like Novalis's Monolog (1798) will dispute this), but do so using arbitrary signs which differ between places and times, suggesting language's 'determination' by society, and moreover subjectivity's determination by language, so long as we cannot fully prise apart thought and word. Thus while Romantic theory makes expansive claims for literature - the best known being Schlegel's that 'Romantic poetry', aka literature, is 'a progressive universal poetry' which is 'alone infinite, as she alone is free' - literature also faces problems which, I suggest, music helps to navigate. ${ }^{10}$ The following is shaped by two methodological approaches to the question of the 'work' of music for literature: word and music studies, and the somewhat newer field of sound studies. The former often concentrates on representations of music and on wordmusic relations in text settings. It is shaped by modernist understandings of the specificity and separateness of the arts, and the poignant gaps between them (for instance, literature is silent and textual; literature aspires to but never achieves polyphony). ${ }^{11}$ Sound studies, meanwhile, following postmodern media and cultural studies, tend to assume the constructed and so changeable nature of divides between media and senses, while striking an anti-elitist stance which can sideline the 'elite'

\footnotetext{
9 Hoffmann, 'Beethovens Instrumental-Musik'.

10 On Schlegel's 'romantic poetry' as 'modern literature', see Matuschek, 'Romanticism as Literary Idealism', 88-90.

11 Louise Hornby, Still Modernism: Photography, Literature, Film (New York: Oxford University Press, 2017), discusses modernism and 'medium specificity'.
} 
sources and close musical and textual analysis often found in word and music studies. Both approaches resonate with Romantic-era and pre-Romantic aesthetics - think, on one hand, of the gulf between visual and verbal arts in Lessing, on the other of Romantic ideals of synaesthesia or the reunification of the faculties (split by modern divisions of labour) in Wagner's Gesamtkunstwerk. But it is sound studies' stronger questioning of the division between the arts which particularly informs this chapter's two broad answers to the question of the 'work' of music.

First, 'music' has a strong role in forming 'literature', as an art, discipline, and institution whose contemporary form emerges in the latter part of the eighteenth century. A well-known marker in this process is a new division between imaginative and non-imaginative literature: in Johnson's 1755 dictionary, 'literature' means 'Learning, skill in letters', but the term has roughly its modern scope around 1800 (for instance, in the English translation of Madame du Staël's De la littérature considérée dans ses rapports avec les institutions sociales (The Influence of Literature on Society, 1812)). Other markers include the establishment in Edinburgh of the first chair in rhetoric and belles lettres, in 1762, held by Hugh Blair, the principal champion of the supposed primitive bard Ossian; and the establishment in the 1770s of 'philology' in German universities (roughly equivalent to Anglo-Saxon language and literature departments). There are also new pedagogical practices, including a stress on learning reading through motherly oralinstruction; changing emotional and imaginative investments in reading; and marked rises in literacy and print. ${ }^{12}$ These coincide with

\footnotetext{
12 Friedrich Kittler, Aufschreibesysteme 1800/1900(Munich: Fink, 1985); Deidre Lynch, Loving Literature: A Cultural History (Chicago: University of Chicago Press, 2015); Andrew Piper, Dreaming in Books: The Making of the Bibliographic Imagination in the Romantic Age (Chicago: Chicago University Press, 2009).
} 
longings for a lost oral immediacy that supposedly existed before modern print culture, with ballad crazes, stylings of poetry as songs, lyrical ballads, or odes, and fashions for improvisation - alongside justifications of written literature as the most comprehensive art after all, reuniting sight, gesture, and sound under the aegis of imagination. ${ }^{13}$

Second, the remainder of this chapter suggests, music helps Romantic literature to fail. Perhaps paradoxically, failure is a key way of responding to and evoking ideals. What is sometimes called the 'literary absolute' flourished in literary theory - a genre, if not separate from, then athwart literary 'works'. Poetry and imaginative prose meanwhile employ music to suggestideals without needing fully to instantiate or capture them, a hubristic task and a self-defeating one insofar as these ideals are infinite and indeterminate. Failure, like music, has varied meanings and uses for Romantic literature, and one of the chief conclusions of this chapter is that, while music often evokes the universal and/or indistinct, there is also a strong alignment between music and particularity. Within the limits of any particular set of aesthetic characteristics or functions, failure thus proves a useful and wide-ranging thread running through the work of music for Romantic literature.

${ }^{13}$ Angela Esterhammer, Romanticism and Improvisation, 1750-1850 (Cambridge: Cambridge University Press, 2008); Maureen McLane, 'Ballads and Bards: British Romantic Orality', Modern Philology, 98 (2001), 423-43; Günter Oesterle, 'Arabeske, Schrift und Poesie in E. T. A. Hoffmanns Kunstmärchen "Der goldne Topf”', Athenäum: Jahrbuch für Romantik, 1 (1991), 60-96. 


\section{Loss of Sound and Certainty: Blake, Hoffmann, Kleist}

The 'Introduction' to William Blake’s 1789 Songs of Innocence (later, following the French Revolutionary Terror, expanded as Songs of Innocence and Experience) is not a prose preface but an energetic poem. Voiced by a rural 'Piper' (line 7), it suggests simple oral origins through compact lines, straightforward and repetitive syntax, an elementary and rough rhyme scheme (abab) and frequently recurring sounds (especially chear, hear, clear (lines 6, 8, 10,12,18, 20)). But the song - if such it is does not insist on oral purity. It is an apparently cheerful parable about the emergence of writing from absolute music, and simultaneously about the genesis and fate of the Songs as a text. ${ }^{14}$ The piper first 'Pip[es] songs of pleasant glee', then, upon the request of a genius- or Christ-like child, gives these songs a programme: 'Pipe a song about a Lamb' (lines 2, 5). He is next told to 'Drop [his] pipe' and 'Sing', and finally to 'sit ... and write / In a book that all may read' (lines 9, 13-14). Making a 'rural pen' from a 'reed', the piper 'wrote [his] happy songs, / Every child may joy to hear' (lines 16-17, 19-20), creating a text that has print's ease of dissemination (all may read) and writing's function as record and script for performance (children may hear).

We might wonder, however, what tune the words will take, if any, and whether something has been lost in the piper's descent from wandering to sitting, from 'valleys wild' to tamer stream (line 1), from pipe to pen, and from an immediate audience with a seraphic child to a merely potential audience of distant children. The poem does not strongly invite a suspicious reading, yet many experienced readers stumble over such questions, and particularly the ambiguity of the piper 'stain[ing] the water clear' (line

\footnotetext{
14 Compare McLane, 'Ballads and Bards', 427-8.
} 
18), apparently with his pen: does writing stain the water dirty, or 'clear' and repristinate it? Moreover, what stains the flowing water, so suggestive of pure origins, and what is the stream's place in writing? Is the water itself an ink, or a writing surface for the dabbling reed? In the absence of Blake or the piper to answer such questions so the ideal of immediate presence goes - readers are free to disagree, freer and less certain than in an oral and musical 'beforehand'. The poem thus constructs not just one 'oral-literate conjunction', in Maureen McLane's words, but several. ${ }^{15}$ It allows us to imagine literature's all-encompassing nature - its paths out of and back into orality and song - but also to question the idyll presented on the page.

A loss of innocence is deepened in German Romantic texts which complicate their oral-literate conjunctions by acknowledging that music, as well as words, can be written, creating complex matrices of music, word, sound, and text. Kleist's 'Die heilige Cäcilie oder die Gewalt der Musik (eine Legende)' (St Cecilia or the Power/Violence of Music (a Legend), 1810) and Hoffmann’s 'Ritter Gluck' (Sir Gluck, 1814), like Grillparzer's Biedermeier novella Der arme Spielmann (The Poor Player, 1847), all turn on unreadable scores. In Kleist's case, a maternal detective-figure approaches the manuscript of a mass by an 'old master', hoping to unlock the secret to the musical experience which miraculously converted her iconoclast sons to Catholicism. But she is musically illiterate, or at least cannot decipher this old notation. Seeing the score's 'unknown magical signs, with which a fearsome spirit seemed mysteriously to define its circle', she 'thought she would sink into the earth'. ${ }^{16}$ She, too, soon converts. What the mother, a truth-seeking Protestant, fails to read is legible by others - namely, the nuns

\footnotetext{
15 McLane, 'Ballads and Bards'.

${ }^{16}$ Kleist, 'Die heilige Cäcilie oder die Gewalt der Musik (eine Legende)' (1810), Sämtliche Werke, 226.
} 
of the apparently wealthy and well-connected convent of St Cecilia - and the reader is left wondering about the roles of divine intervention as against worldly power plays and obfuscation in the Protestants' return to the old faith. In Hoffmann's case, an apparition of the dead composer Gluck plays from a richly bound and printed score, yet its notes are invisible to the dilettante narrator - either a sign of his musicalphilosophical tone-deafness (for he misunderstands the genius), or the sheer impossibility of translating the infinite, teeming, polymorphous 'forms' (Gestalten) of ideal creativity into quotidian life on the page, the letter that kills while the spirit gives life. With Grillparzer, we meet a musical text as botched and cramped as the aspirations of its atrocious 'beggar-musician' to unstained personal and musical harmony in a fallen world. ${ }^{17}$

In each story, music represents for some characters an ideal experience which, to others, looks or sounds incomprehensible. The fact that music is not immediately present within these literary prose texts - as sound or as writing - allows them to stage a gap between the ideal and the prosaic (the latter aligned with the writer-narrator), and furthermore to pass on this gap to the reader as a failure of certainty, the impossibility of contact with a musical 'source' which might prove whether the ideal was an illusion all along or not. This kind of useful failure, created by writers who were themselves composers, players, or commentators on music, contrasts sharply with the desirable failure of musical ideals with a Romantic such as Coleridge.

\footnotetext{
${ }^{17}$ Franz Grillparzer, Der arme Spielmann. Anmerkungen und Nachwort von Helmut Bachmaier (Stuttgart: Reclam, 2002), 7.
} 


\section{Avoiding the Ideal: Coleridge}

One of Coleridge's best-known treatments of music is 'The Eolian Harp' (1796). This rural and domestic idyll sees the poet sitting with his future wife, musing on the philosophical implications of sounds emanating from an aeolian harp. This instrument fascinated Romantic listeners because it was played by the wind, seeming to activate and manifest the creativity and harmony of nature (even 'the mute still air / Is Music slumbering on her instrument' (lines 33-34)). For Coleridge, the harp suggests first eroticism ('caress'd, / Like some coy maid' (lines 15-16)); then the supernatural ('a soft floating witchery of sound'(line 20)); then more elevated philosophical materialism, influenced by Enlightenment nerve theory - Coleridge engaged especially with Hartley's idea that solid nerves, vibrating like instrument strings, grounded all sense perception, movement, and thought - theory tainted by association with scepticism and pantheism. ${ }^{18}$ The speaker distances his philosophising from scepticism, and recalls the Neoplatonic Christian imagery of a world soul (long associated with music) as well as Romantic scientific work on the underlying unity of sensation and life: there is

one Life within us and abroad,

Which meets all motion and becomes its soul,

A light in sound, a sound-like power in light,

Rhythm in all thought, and joyance every where. (lines 27-30)

Yet still he imagines his 'passive brain' being given thoughts, as the harp is given melodies by 'random gales', and wonders 'what if all of animated nature / Be but organic Harps diversely fram'd, / That tremble into thought, as' they are swept by 'one

\footnotetext{
${ }^{18}$ See further Shelley Trower, Senses of Vibration: A History of the Pleasure and Pain of Sound (New York: Continuum, 2012), 13-26.
} 
intellectual breeze', 'the Soul of each, and God of all?' (lines 42-43, 45-9) All this looks ideal: a vision of organic and spiritual unity, and one not only formulated intellectually, but suggested by, even on a continuum with, an empirical musical experience. Moved by music, as harp strings are moved by the wind, the poem seems to enact that flow between individual and universal, mechanical 'motion' and 'soul,' which it describes (line 28). Similar musical visions appear in Schlegel's Abendröte (Sunset, 1802) - where 'Everything seems to speak to the poet / For he has found the meaning, / And the universe [seems] a single choir, / Many songs from One mouth' - or Eichendorff's miniature 'Wünschelrute' (Divining Rod, 1838):

A song sleeps in all things

Which lie dreaming, on and on,

And the world begins to sing

If only you hit upon the magic word.

With Coleridge, however, the ideal and the aural idyll are not the final word. In the last stanza, the speaker accepts the 'mild reproof' of his beloved's 'more serious eye', and abandons his 'unhallow'd' speculations (or, perhaps better, 'auscultations', since this is philosophy as listening) (lines 50,52). ${ }^{19}$ Joy and contentment - the poet's 'Peace, and this Cot, and thee, heart-honour'd Maid!' (line 65) - arise not from musical nature revealing itself naturally to poet-philosophers, but from the intervention of the biblical God, 'saving' broken natures and revealed, partially, in scripture (line 62). Likewise, proper poetry emerges not as enthusiastic invention, flowing from 'vain Philosophy's aye-babbling spring', but humble 'praise' of God, 'The Incomprehensible!' (lines 58, 60-

${ }^{19}$ For an influential discussion of auscultation, see Jonathan Sterne, The Audible Past: Cultural Origins of Sound Reproduction (Durham, NC: Duke University Press, 2003), 100-137. 
61) Readers may regard the final stanza as marring the poem's shape and sentiments. But, for the speaker, claims to ideal plenitude are dangerous, and failure to embody it a saving grace. Poetry responds to the pressures of the given: not a world spirit but actual community (the female companion), revealed religion (and its limits), and, more mutedly, an inherited poetic tradition of rural contentment, taken from Virgil'sGeorgics. In this long tradition, philosophical speculation on nature is situated within quietrural landscapes, like the one with which Coleridge begins (where "The stilly murmur of the distant Sea / Tells us of silence' (lines 11-12)); and, while Virgil's poet-speaker asks the muses for philosophical enlightenment and elevation, he then falls back into the more humble request for a quiet life and unspectacular contentment (Georgics 2.475-89). An internal tension between sound, music, and quiet thus runs through the poem, and prepares the well-tuned reader for the fact that 'wild', 'delicious', exuberant music will help poetry to reach its necessary domestication and falling-short (lines 25,20$)$.

Music plays a no less pivotal role in perhaps the best-known Romantic failure in poetry, Coleridge’s ‘Kubla Khan’ (1797/1816). In a preface which by its nature underscores the poem's lack of self-sufficiency (as will the marginal notes in 'The Rime of the Ancient Mariner'), Coleridge reports that he published this 'fragment' at the request of Byron, 'rather as a psychological curiosity, than on the ground of any supposed poetic merits'. Romantic tropes of the exotic or 'other', spontaneous, and ideal are on full display. During a vivid opium dream, inspired by reading an antique travelogue which narrated the still older history of the Mongol khan Kublai, the author experienced a spell of spontaneous 'composition'. This original poem was composed in an ideal psycho-physiological state, 'without any sensation or consciousness of effort', and an ideal quasi-Adamic language, whose 'expressions' 'correspond[ed]' perfectly 
with the 'things' they represented. Seeming 'to have a distinct recollection of the whole' upon awakening, Coleridge 'instantly and eagerly wrote down the lines' we know as 'Kubla Khan' before being interrupted by a visitor from the quotidian world. Fled was the vision, and the remaining 150-250-odd lines of poetry Coleridge imagined himself to have composed in his altered state. 'Kubla Khan' is thus presented as a monument to a lost ideal poetic experience - a witness to a 'whole' that is all the more evocative of perfection for being itself broken. The imaginative stakes are high, but the pressures on the words on the page relatively low. Internally, the poem also describes imperilled, utopian perfection. First, there is the 'miracle of rare device' that is Kubla Khan's heterotopic 'pleasure-dome', arising as if by magic through his creative 'decree' and seemingly channelling the violent forces of nature (lines 35, 2). Yet its pleasures and musical 'mingled measure' cannot drown out the labours of kingship, the sound of 'Ancestral voices prophesying war!' (lines 33, 30)

Third-person description now breaks off, replaced by a first-person reflection on a past 'vision' of an 'Abyssinian' 'damsel with a dulcimer.' (lines 37-39) She sings of another artificial paradise, Abyssinia's 'Mount Abora' (line 41). The speaker's nowindistinct 'vision' was apparently sonic - although the visual term builds in extra distance between reader and music - since its (non)sounds become a stimulus for his own potential construction of an artificial paradise:

Could I revive within me

Her symphony and song,

To such a deep delight 'twould win me,

That with music loud and long,

I would build that dome in air, 
That sunny dome! those caves of ice! (lines 42-47)

This conditional act of creation with its lost possible ground - music - is bracketed one further step by the hypothetical reaction of 'all who heard' the music: 'all should cry, Beware! Beware!' at the enthusiastic (and implicitly opiated) creator, should enclose him in a quasi-magical, protective triple 'circle' and close their eyes to him (lines 48-49, 51). The underlying structure here is significant: an exotic woman, singing about a legendary mountain in her native land - one long associated with the hidden source of the sacred river Nile - represents poetic creation's lost source of plenitude (a 'loud and long' 'symphony', or sounding-together (lines 45, 43)). Moreover, as lost, the singer represents the stimulus for the existing poetic fragment, in its mode of imperfect recollection, wish, or lament, strategically distanced from an encircled ideal.

Coleridge's very different treatments of strange stringed instruments in these poems use music to figure an ideal which it is actually in the poem's interests to avoid. 'Kubla Khan' arguably has a pragmatic rationale for avoidance: the perfection of altered states cannot be communicated directly, and gesturing towards their loss becomes a good bet in persuading readers something was really there. But in both poems there is a dimension of moral danger and delusion in the ideal that makes failure to reach it valuable. What explains this danger and its alignment with music? It should be acknowledged that the scenario does not fully capture the range of music's work for Coleridge, let alone for other English Romantics, and figures including Fanny Burney, Leigh Hunt, William Hazlitt, the Shelleys, and Thomas De Quincey engaged more closely and positively with musical culture. Nonetheless, the lurking suspicion of music in the two poems perhaps holds some trace of broader English Protestant suspicions of music 
as sensual distraction and self-display. ${ }^{20}$ If not typical, the poems find many echoes elsewhere. The moral questions raised in 'The Eolian Harp' are shared by Wordsworth's ambivalent depiction of excessive musical absorption in 'The Power of Music'. Meanwhile, the less clearly denounced artificial paradise of Coleridge's opium vision is echoed by De Quincey's depiction of the 'Pleasures of Opium' in his Confessions of an English Opium-Eater(1821) - recalled from the other side of this 'Paradise', when he has suffered and apparently overcome the 'Pains of Opium'. Opium's pleasures are epitomised by visits to the opera, where he heard alongside opera singers the passionate 'music' of Italian women speaking in the audience, a musicality enhanced by its separation from utilitarian signification - since De Quincey understood no Italian and which he compared with the musicality of 'Indian' women's speech, as recounted by a contemporary traveller to Canada. ${ }^{21}$

The connection of music with exotic women's language deserves further exploration. It suggests associations of music with the non-semantic, a- or irrational, undetermined and vague; with passion, sensuality, wildness; and with racial, national, epistemological, and gendered otherness. These are alterities that modern male European authors might claim to harness and mediate to readers without embodying them, making music a useful 'constitutive other' for literature. But the exotic woman can also suggest music's associations with things more particular, determinate, and grounded, leading us to a final and complex case of literary failure.

\footnotetext{
20 On English Romantic wariness of virtuosity and praise of 'natural' performance, see Gillen D'Arcy Wood, Romanticism and Music Culture in Britain (Cambridge, 2010). 21 The Works of Thomas De Quincey, ed. Grevel Lindop et al. (London: Pickering \& Chatto, 2000-03), vol. 2, 334.
} 


\section{Exoticism and Philological Failure: Mérimée}

Prosper Mérimée's novella Carmen (1845/47) is not always counted among the Romantic works of this archaeologist, historical conservationist, and master of short fiction. Yet it reflects and interrogates key developments stemming from Romantic-era literature and literary-critical method, still important to the discipline today - namely historicism and hermeneutical philology. Nor is Carmen obviously concerned with music: despite her name, and unlike Bizet's gypsy, Mérimée’s does not seduce through song. Music is incidental, scattered through the novella, integrated into larger soundscapes and broader depictions of character, custom, and place.

This is as it should be in a novella shaped by historicism, a term coined by Friedrich Schlegel but with roots in Enlightenment-era philosophy and its reception by Herder and others. ${ }^{22}$ Historicism assumed that character and action vary across nations and their specific stages of historical development; influenced by history, national languages are great repositories and transmitters of cultural specificity, revealing a people's nature and pointing to its origins. For Herder, the origins of language and song were conjoined. The first language indeed was song, and present-day orally preserved folk songs offered a better insight into the spirit of a people than more alienated modern languages. Within the historicist paradigm, consciously or not (self-consciously in Mérimée’s case), literary authors will show the organic connection between language, social milieu, and individual plots. Literary historians and critics will give close

\footnotetext{
22 See Edward Said, 'Introduction', in Erich Auerbach, Mimesis: The Representation of Reality in Western Literature, trans. Willard R. Trask (Princeton: Princeton University Press, 2013), ix-xxxii, at xii-xvi. Further James Chandler, England in 1819: The Politics of Literary Culture and the Case of Romantic Historicism (Chicago: University of Chicago Press, 1998).
} 
attention to the specificities of language (philology) in order to interpret or divine a text's original meaning (the hermeneutic task). While German Romantics are usually held to have concentrated on the specificities of distant lands or times, especially the Middle Ages, Mérimée's friend Stendhal is credited with applying historicism to the here and now, showing in his realist novels how both unremarkable everyday mores and apparently idiosyncratic individual fates are shaped by larger socio-historical forces. ${ }^{23}$ Tellingly, Stendhal connected music with national origins and specificities in his Memoirs of Rossini (1824), recounting how the changeable timbres of Giuditta Pasta's voice inspired in an exiled Neapolitan a vivid moonlit vision of his 'unhappy homeland'.

Set in near-modern-day Spain, Mérimée’s Carmen combines realism with a romanticising, exotic location. Philology and historical interpretation are built into its premise: the narrator is a travelling French dilettante-scholar who comes across Carmen's lover and murderer, Don José, during an archaeological 'excursion' which he hopes will prove the exact site of the classical Battle of Munda, a 'fascinating question' supposedly 'holding all learned Europe in suspense'. ${ }^{24}$ The narrator recounts the 'little story' of Carmen to fill in time before his dissertation on Munda's origin takes the scholarly world by storm. We soon find he is also a keen linguist and ethnographer, recording in footnotes details of language use (Carmen switches between Spanish, Basque, and 'chipe call'), pronunciation, and telling idioms, and using his observations in faltering attempts to discern the geographical and 'national' origins of Don José and Carmen herself (mistaken for an Andalusian, a Moor, or a Jewess).

\footnotetext{
23 Auerbach, Mimesis, ch. 18.

24 For English translations, see Prosper Mérimée, Carmen and Other Stories, trans. Nicholas Jotcham (Oxford: Oxford University Press, 1989), here 1 (subsequent page numbers are provided in the text in parentheses).
} 
Music and sound are crucial here. The undercover bandit José is initially taciturn (a stance affirmed in the novella's last sentence, which quotes a 'gypsy' proverb, 'A closed mouth, no fly can enter' (339)). The pronunciation of José's 'first words' mark him as a stranger in Andalusia (3). But only his singing to a mandolin, with incomprehensible words and a 'melody plaintive and exotic', suggests to the narrator that he is specifically Basque (7). The song - a characteristic 'zortziko' - affects José in a way that on one hand reveals his ethnic traits and origins, and on the other hints at his individual character and fate. José grows 'sombre', 'profound[ly] melancholy', and resembles 'Milton's Satan.' 'Perhaps, like' that Romantic antihero, he is brooding on 'the abode he had left behind [Heaven/Navarre], and of the exile he had earned by some transgression.' (7) (The same is true of Carmen's only conventional musical performance, a romalis dance for a high-society party. Glimpsing this dance accompanied by 'tambourine' and 'guitar', José 'fell in love with her in earnest' - yet he introduces this pivotal personal moment in quasi-historicist, sociological terms, as generally characteristic of gypsies and their place in Spanish society: 'They always have an old woman ... and an old man with a guitar ... . As you know, Gypsies are often invited to social gatherings to entertain guests' $\left.(27-8) .{ }^{25}\right)$

José's melancholy seems not simply associative, but directly prompted by sound's affective and aesthetic qualities. For, much later, he tells the narrator: 'Our language is so beautiful, señor, that when we hear it spoken far from home our hearts

25 Compare Mérimée's aim in his Romantic historical novel Chronique de règne de Charles IX (1829) of creating '[u]ne peinture vraie des mœurs et des caractères à une époque donnée' (a true picture of the customs and characters of a given epoque), and his combination there of what Charlton identifies as a passion for 'significant details and revealing anecdotes' with flattened character 'types'. Donald Charlton, 'Prose Fiction', in The French Romantics, 2 vols. (Cambridge: Cambridge University Press, 1984), vol. 1, 189, 195. 
leap at the sound of it.' (23) Rousseau had linked sound with nostalgia - originally a longing for a specific place, one's homeland - citing Swiss soldiers' propensity to fall fatally ill if they heard their native (verbally incomprensible) cow-herding songs in distant lands. This trope has a decisive narrative function in Carmen: when José, then a soldier, arrests Carmen for attacking her fellow worker, it is Carmen's recognition of José’s Basque accent, her ability as a polyglot gypsy to speak Basque, and her false claim to be José's compatriot which persuade him to let her escape. This plunges him into a series of punishments and transgressions ending in the lovers' isolation and deaths. The sonic effect is double-pronged, specific and general; since not only Basque, but Carmen's vocalising in any language (along with her laughter) always overpowers José's reason, he claims, making him a 'fool', 'drunken', 'mad', bending him irresistibly to her will (24). José's response to Carmen's voice suggests a kind of sympathetic magic: sound makes him resemble her wild and exotic character. The cluster of associations madness, drunkenness, magic, transgression, passion, exoticism - belongs to cultural clichés about music as 'other' to modern rationality and rule-bound civilisation. Music represents an alluring ideal of sorts - freedoms, extremes, and rebellions in an age of staid moderation, inertia, and inward-looking pedantry (recall the 'fascinating' question of Munda) - but not an ideal realist literature can straightforwardly embrace. Mérimée deploys these associations in Carmen's incidental uses of music. The lovers' first orgiastic one-night stand begins with Carmen 'danc[ing] and laugh[ing] like a madwoman, singing, "You are my rom [husband], I am your romi [wife]"', before violently smashing an old woman's 'only plate' to fashion makeshift castanets (30). Like her other words, Carmen's song lies: she is already married. But on another level the music is incantatory and interpellative, helping to effect José's deracination and 
transformation from an honour-bound Basque-speaker into something like a Roma. After the resurfacing of Carmen's real rom, she will idly sing and 'rattl[e] her castanets' as a cover for kissing José at their shared campsite (prompting his accusation, 'You are the Devil incarnate', to which she replies, 'Yes' (39)). She 'clack[s] her castanets' like protective talismans or noisy carnival instruments to 'banish' any 'disturbing idea' (46), and just before her death, 'engrossed' in a weird mental state as she undertakes rituals that predict her murder, she 'sing[s]' 'magic songs invoking' the original 'great Queen of the Gypsies' (51).

This is a world where sounds are identifiers and signatures, typifying characters and groups like the timbre of an instrument. José has his Basque accent; the narrator a repeating watch (a novelty in Spain, leading Carmen to misidentify him as an uppercrust Englishman); even King Pedro I, a footnote claims, was easily recognised in a dark alley by an old woman through his 'extraordinary disability' of 'loudly' 'crack[ing]' 'knee-joints' (29). Carmen has her castanets, but gypsy sounds are also an anomaly and problem for the narrator's methods. Polyglot, code-switching, wild, magical - these sounds of course delocalise and exoticise gypsies, failing to specify their origins or locality. The novella's belated fourth instalment, a free-standing ethnographic sketch of the gypsies, hammers home the anomaly. Their pre-European origins are unknown; their reasons for migrating unknown; 'strangest of all, no one knows how ... their numbers soon increased so prodigiously in several countries so far apart' (337) - in other words, even the assumption that peoples emanate from single origins is undermined. Finally, the origin of gypsy language is unsettled, and, flouting the logic of hermeneutic philology and the tie between nation and speech, '[e]verywhere they speak the language of their adopted country in preference to their own' (337). 
These anomalies help the novella to stage its failures and instal its central character as, not merely an enigmatic femme fatale in the tradition of French literature, but an inscrutable force of resistance and autonomy who tells her lover, 'you have the right to kill your romi. But Carmen will always be free' (52). José's failure to control Carmen, and the narrator's scholarly failure fully to place the gypsies in general and Carmen in particular, join a series of imperfections: the lovers' deaths and failed relationship; half-accidental murders; incomplete linguistic crossings (Basque and chipe calli are essentially closed to the narrator, and even Carmen speaks the former 'atrociously' (24)); the forever-suspended proof that the narrator has located Munda; incomplete plot arcs (characteristic of modern short fiction) concerning José's death and the narrator's promise to return a medallion to José's mother at home - narrative promises of closure or return to origins left hanging by the focus on Carmen's end. As in 'Kubla Khan', music helps to evoke lost origins, wholeness, and creative freedoms not possessed by the literary work itself judged as a set of words on the page. It creates something like a 'transcendence' or 'ideality effect', a sense of something further that literature can strive to become and represent.

\section{Conclusion}

However unappealing the stereotypes of music in a text like Carmen, the work of music within this novella and the other examples discussed aligns it with the aspirations of Romantic literature as defined by Schlegel:

Other kinds of poetry are complete and can now be fully analysed. The romantic kind of poetry is still becoming; indeed, that is its actual essence, that it can only eternally become, never be complete. ... Only she is 
infinite, because only she is free and acknowledges, as her first law, that the caprice of the poet suffers no law above itself. ${ }^{26}$

Schlegel's definition is both infinitely demanding and absolves literary works of embodying any perfections - classically associated with completeness - or living up to any particular ideal, since standards would make poetry determined and unfree. The 'ideal' of Romantic poetry can only be provided by 'a divinatory criticism' like Schlegel's, not by analysing a canon of extant exemplary works. ${ }^{27}$ Romantic poetry is great in theory; in practice, in order to 'never be complete' it frequently cultivates smallness, showy incompleteness, and failure. Although Schlegel claims that Romantic literature has no real boundaries - 'encompass[ing]' multiple arts, non-arts like philosophy, and the 'artless song' breathed out by a 'child' - nevertheless one of the most effective 'caprices' of Romantic writers is precisely to construct limits and acknowledge laws above and outside literature - perhaps above all the law of music.

Methodologically, this observation brings home a foundational argument of media studies, now also important for sound studies and musicology, that different media have porous and changing boundaries, and, in Georgina Born's words, exist 'relationally'. ${ }^{28}$ This insight encourages us to see relationships between literature and music within the broader framework of sound, and to attend to matters as seemingly external to music as hermeneutic philology. This reinforces the fact that the 'work' of music for literature extends beyond any trope or structure such as failure, to forming the institution and discipline of literature itself. Nonetheless, the uses and timbres of

\footnotetext{
${ }^{26}$ Schlegel, Athenäum fragment 116, 37-8.

27 Ibid.

${ }^{28}$ Georgina Born, 'For a Relational Musicology: Music and Interdisciplinarity, Beyond the Practice Turn', Journal of the Royal Musical Association, 135 (2010).
} 
failure are manifold and revealing. It might spur melancholy, frustration, madness, longing, humility, suspicion, or an awareness of interdependence. Its flipside is promise and possibility - the sense taken from Romanticism into the commonplaces of later culture: that life and art are epitomised by 'Effort, and expectation, and desire, / And something ever more about to be' (Wordsworth (Prelude, 1805, 6.541-2)); the drive 'To strive, to seek, to find, and not to yield' (Tennyson ('Ulysses', 1833, line 70)); that the failure of pleasure drives the formation of civilisation and individual psyches (Freud); or that, in words claimed by postmodernist ironists and popular self-help books alike, we are condemned and free to 'Try Again. Fail Again. Fail Better' (Beckett ('Worstward Ho', 1983)). Even E. M. Forster has a little of it when he declares in 'Not Listening to Music' (1939) - a celebration of his failure to concentrate on or write about music - that while his 'own performances upon the piano' (usually Beethoven) 'grow worse yearly', 'never will [he] give them up': 'Even when people play as badly as I do, they should continue: it will help them to listen.' 


\section{University Library}

\section{- M M I N E R VA A gateway to Melbourne's research publications}

Minerva Access is the Institutional Repository of The University of Melbourne

Author/s:

Stanyon, M

Title:

Music and Romantic Literature

Date:

2021-08-06

Citation:

Stanyon, M. (2021). Music and Romantic Literature. Taylor, B (Ed.). The Cambridge Companion to Music and Romanticism, (1), pp.37-55. Cambridge University Press.

Persistent Link:

http://hdl.handle.net/11343/285049 